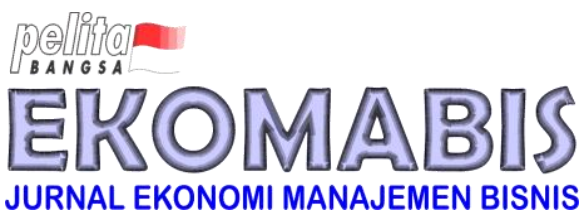

\title{
Pengaruh Harga dan Kualitas Pelayanan Garuda Express Delivery (GED) Terhadap Kepuasan Pelanggan
}

\section{(The Effect of Price and Service Quality for Garuda Express Delivery (GED) on Customer Satisfaction)}

\begin{abstract}
Abstrak
Tujuan penelitian ini untuk mengetahui pengaruh harga dan kualitas pelayanan yang diberikan oleh ekspedisi Garuda Express Delivery (GED) terhadap kepuasan PT IDS Medical Systems Indonesia (Cabang Jakarta). Objek penelitian ini adalah karyawan pada PT IDS Medical Systems Indonesia (Cabang Jakarta) yang merupakan pelanggan layanan ekspedisi GED. Penelitian berbasis metode kuantitaif, melalui survey menggunakan kuesioner. Teknik sampling berupa sensus melibatkan divisi Logistik dan SOM (Sales Order Management) sebanyak 28 karyawan. Data diolah dengan analisis regresi linier berganda menggunakan SPSS 21. Hasil penelitian ini menunjukkan kepuasan konsumen tidak dipengaruhi oleh harga. Pada sisi lain, kualitas pelayanan berpengaruh signifikan terhadap kepuasan.

Kata Kunci : Harga, Kualitas Pelayanan, Kepuasan Pelanggan
\end{abstract}

\begin{abstract}
The purpose of this study was to determine the effect of price and service quality provided by the Garuda Express Delivery (GED) expedition on the satisfaction of PT IDS Medical Systems Indonesia (Jakarta Branch). The object of this research is an employee at PT IDS Medical Systems Indonesia (Jakarta Branch) which is a customer of the GED expedition service. Quantitative method-based research, through a survey using a questionnaire. The sampling technique is in the form of a census involving the Logistics and SOM (Sales Order Management) division of 28 employees. The data is processed by multiple linear regression analysis using SPSS 21. The results of this study indicate that consumer satisfaction is not influenced by price. On the other hand, service quality has a significant effect on satisfaction.
\end{abstract}

Keywords: Price, Service Quality, Customer Satisfaction

1 STIE IPWI Jakarta; agus.sudigdo@gmail.com

2 STIE IPWI Jakarta; alwitaufik@yahoo.com 


\section{Pendahuluan}

Distribusi produk yang dihasilkan dari berbagai entitas bisnis sering terkait dengan layanan pengiriman barang berupa ekpedisi maupun dalam bentuk delivery. Perkembangan model layanan bisnis yang berbasis online melalui penggunaan digital platform dan internet menuntut penyesuaian dan inovasi berkelanjutan. Selama masa pandemi Covid-19, tidak sedikit industri yang terkontraksi akibat pembatasan mobilitas seperti pada industri ritel, pariwisata, dan hotel. Di sisi lain, secara dinamis terdapat industri yang stabil dan bertahap mengalami trend berkembang terjadi pada industri ekspedisi dan kurir termasuk untuk produk kesehatan, seiring berkembangnya solusi aplikasi platform online (Taufik \& Ayuningtyas, 2020). Kompetisi bisnis yang tinggi pada bisnis ekspedisi dan jasa kurir semakin menuntut inovasi bisnis dalam menghadirkan layanan unggul bagi konsumen.

Peluang tersebut telah banyak dimanfaatkan oleh banyak perusahaan seperti Garuda Express Delivery (GED), TOTAL, M2M, Mas Kargo demikian juga PT Pos Indonesia, Elteha International, TIKI, JNE, J\&T Express, dan Si Cepat. Beberapa penelitian mengenai kepuasan konsumen layanan ekspedisi dan kurir semakin menunjukkan pentingnya upaya peningkatan kepuasan konsumen (Novia \& Sutrisna, 2017; Apriati et al., 2018; Novia \& Sutrisna, 2017; Anshar, 2019; Setiawan \& Frianto, 2021).

PT IDS Medical Systems Indonesia merupakan bagian dari network distribusi IDS Medical Systems Group, untuk kawasan Asia Pasifik. PT IDS Medical Systems Indonesia melayani distribusi puluhan merek produk medis global berupa peralatan medis dan barang habis pakai medis. Dalam memberikan pelayanan kepada pelanggannya PT IDS Medical Systems Indonesia bekerjasama dengan 4 ekspedisi yakni, Garuda Express Delivery (GED), TOTAL, M2M dan Mas Kargo. Dari ke 4 ekspedisi tersebut Garuda Express Delivery (GED) adalah ekspedisi terlama yang telah bekerjasama dengan PT. IDS Medical Systems, yaitu sejak tahun 2018. Sebagai perusahaan yang bergerak di bisnis kargo dan logistik Garuda Express Delivery (GED) membutuhkan upaya berkelanjutan dalam perbaikan kualitas layanan kepada konsumen. Selain hal tersebut, GED harus bisa menghindari masalah-masalah yang terjadi. Baik atau buruk pelayanan yang diberikan GED akan mempengaruhi kepuasan dari PT IDS Medical Systems Indonesia.

Saat ini, meraih kepuasan pelanggan (customer satisfaction) menjadi tantangan besar setiap entitas bisnis dalam setiap interaksinya dengan konsumen. Performa dari setiap layanan akan direspon positif jika kebutuhan dan keinginan konsumen terpenuhi serta sesuai dengan harapan konsumen. Idealnya, capaian pelayanan konsumen akan semakin tinggi bila mampu memberikan pelayanan yang melebihi harapan konsumen, sehingga akan membentuk kepuasan konsumen. Hal ini, secara jangka Panjang dapat memberikan kontribusi lanjutan berupa terbentuknya konsumen yang loyal terhadap pelayanan yang diberikan oleh perusahaan.

Fenomena umum menunjukkan bahwa kepuasan konsumen yang bisa diketahui dari persepsi pada sudut pandang konsumen, tidak terlepas dari kemampuan setiap entitas bisnis dalam memenuhi kebutuhan (needs) dan keinginan (wants) serta harapan (expectation) dari konsumen. Secara dinamis perusahaan dapat menyesuaikan permintaan pasar dengan inovasi layanan yang disertai atensi pada kualitas pelayanan. Kualitas layanan merupakan totalitas sifat atau ciri produk atau pelayanan terkait dengan kemampuannya untuk memuaskan kebutuhan konsumen (Kotler \& Keller, 
2009). Pada sisi lain, harga (price) yang ditetapkan pada setiap jenis produk atau layanan secara bertahap akan direspon oleh konsumen yang berlanjut pada tingkat kepuasan dari konsumen selaku pengguna produk atau jasa. Sensitifitas konsumen dalam memilih beragam alternatif produk tidak terlepas dari harga pada masing-masing produk atau jasa. Setiap harga yang dibayar oleh konsumen selalu terkait dengan upaya memperoleh benefit dari setiap produk yang dibeli (Kotler \& Amstrong, 2012). Kesesuaian antara harapan konsumen dengan sejumlah harga yang dikeluarkan dalam menggunakan suatu layanan ekspedisi akan mempengaruhi kepuasan konsumen.

Banyak penelitian yang terfokus pada faktor harga sebagai salah satu pembentuk kepuasan konsumen. Terdapat beberapa penelitian terdahulu yang menemukan adanya pengaruh positif antara harga terhadap kepuasan konsumen pada layanan pengiriman barang. Penelitian tersebut antara lain penelitian pada perusahaan JNE di Pekanbaru (Novia \& Sutrisna, 2017), penelitian pada perusahaan J\&T Probolinggo (Apriati et al., 2018), dan penelitian JNE Surabaya (Anshar, 2019). Hasil penelitian yang berbeda ditemukan bahwa harga tidak berpengaruh terhadap kepuasan konsumen (Setyo, 2017).

Pada sisi lain, aspek pelayanan juga berpengaruh positif terhadap kepuasan konsumen. Beberapa penelitian terdahulu menemukan adanya pengaruh positif antara kualitas layanan perusahaan jasa pengiriman barang terhadap kepuasan konsumen. Penelitian tersebut antara lain pada konsumen JNE Pekanbaru (Novia \& Sutrisna, 2017), penelitian pada konsumen J\&T di Probolinggo (Apriati et al., 2018), jasa pengiriman barang JNE Surabaya (Anshar, 2019), dan Jasa ekspedisi Krian (Setiawan \& Frianto, 2021). Pada sisi lain, terdapat penelitian yang menemukan pengaruh yang lemah dari kualitas layanan terhadap kepuasan konsumen (Siregar, 2020).

Berdasarkan adanya kesenjangan penelitian terdahulu mengenai pro dan kontra dari kepuasan pelanggan yang dipengaruhi oleh faktor harga (price) dan kualitas pelayanan (service quality), penelitian ini akan mengeksplorasi bagaimana harga dan kualitas pelayanan dalam mempengaruhi kepuasan pelanggan, khususnya pada layanan ekspedisi berbasis produk kesehatan. Distribusi dan permintaan produk kesehatan di masa pandemi Covid-19 menarik diteliti terutama pada aspek kepuasan konsumen yang dipengaruhi oleh faktor harga dan kualitas pelayanan jasa ekspedisi atau kurir pada level perusahaan, yaitu PT IDS Medical Systems Indonesia khususnya cabang Jakarta dari layanan ekspedisi Garuda Express Delivery (GED). Penelitian sebelumnya, tidak terfokus pada produk kesehatan dan hanya meneliti konsumen perorangan (end user).

\section{Metodologi}

\subsection{Pengembangan Model}

\subsubsection{Kepuasan Pelanggan}

Kepuasan pelanggan merupakan konsekuensi dari adanya perbandingan yang dilakukan oleh pelanggan yaitu dengan membandingkan antara tingkat manfaat yang sesungguhnya dirasakan pelanggan terhadap manfaat yang diharapkan. Kepuasan pelanggan (customer satisfaction) terkait dengan persepsi konsumen dalam melakukan komparasi antara benefit diharapkan dengan yang nyata dirasakan. Komparasi tersebut memiliki konsekuensi pada munculnya kekecewaan atau pun kesenangan sebagai 
dampak atau pun impact dari penilaian atas performa produk atau jasa yang dikonsumsi (Kotler \& Keller, 2009).

\subsubsection{Variabel harga terhadap kepuasan}

Kebijakan harga yang diterapkan oleh setiap perusahaan merupakan faktor yang mampu menciptakan kepuasan pelanggan. Harga sebuah produk merupakan faktor penentu permintaan tersebut. Hal tersebut menjadi faktor penting yang perlu mendapat atensi dari perusahaan

Setiap harga yang dibayar oleh konsumen selalu terkait dengan upaya memperoleh benefit dari setiap produk yang dibeli (Kotler \& Amstrong, 2012). Penentuan harga pada setiap jenis produk atau layanan secara bertahap akan direspon oleh konsumen yang berlanjut pada tingkat kepuasan dari konsumen selaku pengguna produk atau jasa..

Penetapan harga dapat dilakukan pada beberapa pendekatan, diantaranya yaitu: (1) Penetration Pricing: berupa penetapan harga yang lebih murah dari pesaing. (2) Parity Pricing: berupa penetapan harga yang mengimbangi harga dari competitor. (3) Premium Pricing: berupa kebijakan harga yang melampaui harga umum yang dierapkan para kompetitor (Tjiptono, 2008).

Salah satu penelitian menyatakan bahwa kepuasan konsumen tidak dipengaruhi oleh harga (Setyo, 2017). Beberapa penelitian lainnya, ditemukan bahwa kepuasan konsumen terbentuk karena pengaruh dari harga. Penelitian tersebut antara lain penelitian pada perusahaan J\&T di Probolinggo dengan sampel sjumlah 82 orang yang difokuskan pada konsumen online shopping dihasilkan temuan bahwa kepuasan pelanggan secara positif dipengaruhi oleh harga (Apriati et al., 2018). Penelitian pada perusahaan JNE di Pekanbaru yang melibatkan 93 responden, ditemukan bahwa kepuasan pelanggan secara positif dipengaruhi oleh harga yang diterapkan di JNE Pekanbaru (Novia \& Sutrisna, 2017). Demikian pula penelitian JNE Gunung Anyar Surabaya pada sejumlah 100 responden ditemukan bahwa kepuasan pelanggan secara positif dipengaruhi oleh harga yang diterapkan di JNE Surabaya (Anshar, 2019).

H1 : variabel harga berpengaruh terhadap kepuasan

\subsubsection{Variabel kualitas pelayanan terhadap kepuasan}

Selain harga, sebagai faktor yang menciptakan kepuasan pelanggan, terdapat juga aspek lain berupa kualitas pelayanan yang diharapkan mendorong kepuasan konsumen. Konsumen akan memberikan dampak positif bagi perusahaan. Tantangan dalam mewujudkan capaian kepuasan pelanggan tidak terlepas dari semakin banyaknya alternatif produk yang ada di pasar dan juga semakin mudahnya konsumen beralih pada pilihan produk lainnya. Kualitas layanan menurut Tjiptono $(2008 ; 85)$ menjadi hal yang sangat esensial untuk dicapai dan dipertahankan guna mewujudkan interaksi yang berkelanjutan.

Beberapa penelitian sebelumnya menjelaskan bahwa kepuasan konsumen dipengaruhi oleh kualitas pelayanan. Seperti penelitian mengenai layanan JNE Surabaya oleh Anshar (2019), penelitian pada konsumen JNE Pekanbaru (Novia \& Sutrisna, 2017), penelitian pada konsumen J\&T di Probolinggo (Apriati et al., 2018). Demikian pula penelitian pada 30 sampel konsumen Jasa ekspedisi Krian (Setiawan \& Frianto, 2021).

H2: variabel kualitas pelayanan berpengaruh terhadap kepuasan 
Tabel 1. Operasionalisasi Variabel

\begin{tabular}{llc}
\hline \multicolumn{1}{c}{ Variabel/ Konsep } & \multicolumn{1}{c}{ Indikator } & Skala \\
\hline $\begin{array}{l}\text { Harga (Kotler \& Amstrong, } \\
\text { 2012), (Tjiptono, 2008). }\end{array}$ & $\begin{array}{l}\text { Penetration Pricing } \\
\text { Parity Pricing } \\
\text { Premium Pricing }\end{array}$ & $1-5$ \\
\hline Kualitas Pelayanan & Realibilty (Kehandalan) & \\
(Tjiptono, 2008). & Responsiveness (Daya Tanggap) & $1-5$ \\
& Assurance (Jaminan) & \\
& Empathy (Empati) & \\
& Tangibles (Bukti Langsung) & \\
\hline Kepuasan (Irawan, 2009). & Kualitas & \\
& Harga & \\
& Service Quality & \\
& Emotional Factor & \\
& Kemudahan & \\
\end{tabular}

Sumber: Rangkuman teori, 2021

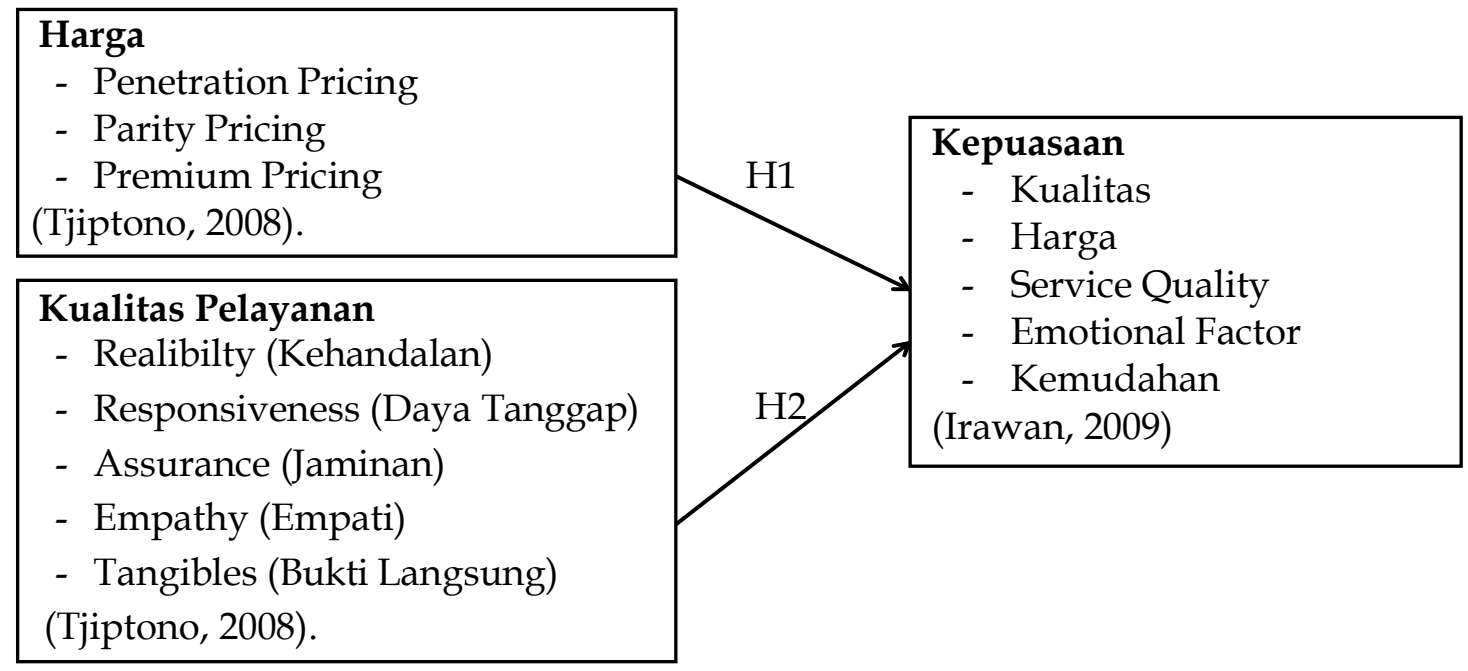

Gambar 1. Kerangka Penelitian

\subsection{Pengumpulan Data}

Penelitian ini merupakan penelitian Survey Explanatory, guna menjelaskan hubungan antara variabel yang diteliti (Sugiyono, 2001). Dalam penelitian ini berupa variabel harga dan layanan terhadap variabel kepuasan pelanggan melalui pengujian hipotesis. Survey dilakukan pada sampel sebagai responden penelitian yang diperoleh dari batasan populasi yang ditetapkan, Teknik sampling yang digunakan berupa sensus atau sampel jenuh. Populasi yang menjadi obyek dalam penelitian ini adalah karyawan idsMED cabang Jakarta yang berhubungan dengan ekspedisi tersebut (GED), yaitu divisi Logistik dan SOM (Sales Order Management) sebanyak 28 karyawan.

Teknik pengumpulan data melalui kuesioner yang dibagikan pada sampel penelitian yaitu karyawan PT IDS Medical Systems Indonesia untuk divisi Logistik dan SOM yang bersedia menjadi responden dan mengisi kuesioner. Variabel-variabel tersebut diukur 
dengan menggunakan data ordinal. Data primer sebagai data utama penelitian diolah dengan software SPSS. Metode deskriptif dan verifikatif diterapkan dalam analisis hasil penelitian.

\subsection{Metode Analisis}

Metode analisis menggunakan statististik deskriptif dan inferensial. Analisis menggunakan SPSS 21. Tahapan Analisis awal berupa uji validitas indikator, reliabilitas indikator penelitian, uji asumsi klasik berupa Uji Normalitas, Uji Multikollinearitäs dan Uji heteroskedastisitas (Mulyanto \& Wulandari, 2010). Selanjutnya pengujian hipotesis melalui Uji t, Uji F dengan persamaan regresi

$\mathrm{Y}=\mathrm{a}+\mathrm{b} 1 \mathrm{X} 1+\mathrm{b} 2 \mathrm{X} 2$

\section{Hasil}

\subsection{Responden}

Data penelitian diperoleh dari 28 karyawan dengan karakteristik yang dirangkum pada tabel 2.

Tabel 2. Data Responden

\begin{tabular}{|c|c|c|c|}
\hline & Variabel & Jumlah & Persen \\
\hline \multicolumn{4}{|c|}{ Jenis Kelamin } \\
\hline - & Perempuan & 11 & 39,3 \\
\hline - & Laki-laki & 17 & 60,7 \\
\hline \multicolumn{4}{|l|}{$\overline{U s i a}$} \\
\hline- & 20-30 tahun & 6 & 21,4 \\
\hline - & 31-40 tahun & 9 & 32,2 \\
\hline - & $41-50$ tahun ke atas & 13 & 46,4 \\
\hline
\end{tabular}

Sumber: Data hasil kuesioner yang diolah, 2021

Tabel 2 menunjukkan data karyawan yang menjadi sampel penelitian sebanyak 28 orang sebagian besar responden laki-laki $(60,7 \%)$, dan usia terbanyak pada kisaran 41 tahun keatas $(46,4 \%)$.

\subsection{Analisis}

\subsubsection{Uji Instrumen}

Tabel 3 menampilkan tiga indikator variabel harga dinyatakan valid karena memiliki nilai korelasi hitung lebih besar dari korelasi tabel $(0,373)$ dan nilai Cronbach alpha variabel harga adalah sebesar 0.882, sedangkan nilai minimal untuk Cronbach alpha adalah 0.60 untuk bisa dikatakan bahwa kuesioner yang digunakan adalah sangat realibel sehingga dapat digunakan untuk melakukan pengukuran dengan tepat. Tujuh indikator variabel kualitas layanan dinyatakan valid dan nilai Cronbach alpha variabel kualita layanan adalah sebesar 0.871, sedangkan nilai minimal untuk Cronbach alpha adalah 0.60 untuk bisa dikatakan bahwa kuesioner yang digunakan adalah sangat realibel sehingga dapat digunakan untuk melakukan pengukuran dengan tepat. Tujuh indikator variabel kepuasan valid dan nilai Cronbach alpha variabel kualita layanan 
adalah sebesar 0.934 , sedangkan nilai minimal untuk Cronbach alpha adalah 0.60 untuk bisa dikatakan bahwa kuesioner yang digunakan adalah sangat realibel sehingga dapat digunakan untuk melakukan pengukuran dengan tepat.

Tabel 3. Uji Instrumen Variabel

\begin{tabular}{ccc}
\hline \multicolumn{1}{c}{ Pernyataan } & R Hitung & Cronbach's Alpha \\
\hline Harga & & 0,882 \\
- Harga awal rendah & 0,384 & \\
- Harga yang sama & 0,849 & \\
- Harga premium & 0,699 & 0,871 \\
\hline Kualitas Layanan & & \\
- Kecepatan layanan & 0,713 & \\
- Kehandalan layanan & 0,829 & \\
- Daya tanggap & 0,825 & \\
- Repon pada konsumen & 0,897 & \\
- Jaminan & 0,882 & \\
- Empati petugas & 0,897 & \\
- Kinerja layanan & 0,861 & \\
\hline Kinerja & & \\
- Kepuasan atas layanan & 0,843 & \\
- Kepuasan atas harga & 0,643 & \\
- Kepuasan atas kesesuaian harga & 0,835 & \\
- Kepuasan atas mutu layanan & 0,793 & \\
- Kepuasan secara emosional & 0,852 & \\
- Kepuasan atas kemudahan akses & 0,930 & \\
- Kemudahan layanan & 0,526 & \\
\hline
\end{tabular}

Sumber : Hasil Pengolahan data, 2021

\subsubsection{Uji Asumsi}

Kolmogorov-Smirnov Test menghasilkan signifikansi $\geq 0,05$ yaitu 0,981 yang menandakan bahwa model regresi telah memenuhi asumsi kenormalan. Hasil uji multikolinieritas yang diperoleh menggunakan program SPSS. Dari hasil uji tersebut diperoleh nilai Tolerance 0,746 > 0,100 serta nilai VIF 1,341 < 10,00. Dengan demikian dapat disimpulkan bahwa tidak terjadi multikolinieritas pada semua variabel. Scatterplot mendapatkan titik-titik data menyebar disekitar angka nol sehingga tidak terjadi masalah heteroskedastisitas, atau model regresi yang baik dapat terpenuhi.

\subsubsection{Uji Model}

Tabel 4 hasil uji F menghasilkan nilai Signifikansi dengan nilai Sig $0.000<0.05$, maka dapat dijelaskan bahwa kepuasan konsumen dipengaruhi oleh harga dan kualitas Pelayanan. Nilai R sebesar 0,795 menunjukkan adanya hubungan yang kuat antara harga dan kualitas pelayanan dengan variabel kepuasan konsumen. Nilai koefisien determinasi (R2) atau R Square dari persamaan regresi adalah sebesar 0,632 atau 63,2\%. Hal ini menunjukkan bahwa 63,2\% perubahan variabel Kepuasan di pengaruhi oleh perubahan variabel Harga dan Kualitas Pelayanan. Sedangkan sisanya sebesar 36,8\% dipengaruhi oleh faktor-faktor lain yang tidak termasuk dalam penelitian ini. 
Tabel 4. Model Summary

\begin{tabular}{ccccccc}
\hline Model & $\mathrm{R}$ & $\mathrm{R}$ & $\begin{array}{c}\text { AdjustedR } \\
\text { Square }\end{array}$ & $\begin{array}{c}\text { Std. Error of the } \\
\text { Estimate }\end{array}$ & $\mathrm{F}$ & Sig. \\
\hline 1 &, $795 \mathrm{a}$ &, 632 &, 602 & 2,370 & 21,443 & 0,000 \\
\hline
\end{tabular}

a. Predictors: (Constant), Kualitas Pelayanan, Harga

b. Dependent Variable: Kepuasan

\subsubsection{Uji Hipotesis}

Tabel 5 mendapatkan Nilai konstanta sebesar 7,365 dengan nilai probabilitas lebih rendah dari taraf uji penelitian $(0,017<0,05)$ yang menandakan nilai konstanta dapat diinterpretasikan. Nilai konstanta memiliki artinya jika variabel harga dan variabel kualitas layanan nilainya nol atau tidak berubah, maka variabel kepuasan konsumen nilainya adalah 7,365 atau positif.

Koefisien regresi variabel harga sebesar 0,353 atau positif; artinya ada indikasi jika variabel harga mengalami kenaikan maka variabel kepuasan akan mengalami peningkatan juga. Namun karena sig. $(0,287)<$ a $(0,05)$ maka koefisien harga terhadap kepuasan tidak signifikan.

Koefisien regresi kualitas layanan diperoleh nilai 0,586 dan signifikan $(0,000<0,05)$ yang menunjukkan bahwa apabila terjadi kenaikan kualitas layanan, maka akan meningkatkan kepuasan konsumen. Koefisien korelasi positif menunjukkan adanya pengaruh positif antara kualitas layanan terhadap kepuasan konsumen, dimana kenaikan pada kualitas layanan maka akan meningkatkan nilai kepuasan konsumen.

Tabel 5. Koefisien Uji Regresi

\begin{tabular}{llccccc}
\hline \multirow{2}{*}{ Model Regresi } & \multicolumn{2}{c}{ Unstand Coefficients } & Stand. Coef. & \multirow{2}{*}{ t } & \multirow{2}{*}{ Sig. } \\
\cline { 3 - 4 } & B & Std. Error & Beta & & \\
\hline 1 & (Constant) & 7,365 & 2,879 & & 2,558 &, 017 \\
& Harga &, 353 &, 325 &, 153 & 1,087 &, 287 \\
& Kualitas Pelayanan &, 586 &, 117 &, 707 & 5,030 &, 000 \\
\hline
\end{tabular}

Sumber: hasil pengolahan data 2021

\section{Pembahasan}

\subsection{Pengaruh Harga Terhadap Kepuasan}

Penelitian mengenai layanan ekspedisi Garuda Express Delivery (GED) pada PT IDS Medical Systems Indonesia menghasilkan perspektif yang unik dimana variabel harga (price) tidak berpengaruh terhadap kepuasan pelanggan. Dalam hal ini konsumen atau pengguna jasa/layanan ekspedisi Garuda Express Delivery (GED) khususnya pada pengiriman produk kesehatan (medical product). Dalam penelitian ini ditemukan bahwa kebijakan harga awal yang lebih rendah, penyeragaman harga atau kebijakan harga yang sama serta penentuan harga premium tidak berpengaruh positif pada kepuasan konsumen. 
Temuan penelitian ini berbeda dengan beberapa penelitian sebelumnya yang meneliti pada jasa pengiriman. Beberapa penelitian seperti penelitian pada perusahaan J\&T di Probolinggo dengan sampel sjumlah 82 orang yang difokuskan pada konsumen online shopping dihasilkan temuan bahwa kepuasan pelanggan dipengaruhi oleh harga (Apriati et al., 2018). Penelitian pada perusahaan JNE di Pekanbaru yang melibatkan 93 responden, ditemukan bahwa kepuasan konsumen dipengaruh secara positif dan signifikan oleh harga yang diterapkan di JNE Pekanbaru (Novia \& Sutrisna, 2017). Demikian pula penelitian JNE Gunung Anyar Surabaya pada sejumlah 100 responden ditemukan ditemukan bahwa kepuasan konsumen dipengaruh secara positif dan signifikan oleh harga yang diterapkan JNE di Surabaya (Anshar, 2019).

Konsekuensi dari temuan ini, tidak terlepas dari kekhasan produk kesehatan PT IDS Medical Systems Indonesia yang dilayani melalui jasa pengiriman oleh ekspedisi Garuda Express Delivery (GED) pada skala layanan business to business atau antara kedua perusahaan tersebut dinilai menjadi salah satu penyebab bahwa variabel harga (harga yang rendah di awal, penyeragaman harga dan harga premium) tidak berpengaruh terhadap kepuasan konsumen. Penekanan pada kebijakan harga bukan sebagai faktor penentu kepuasan konsumen pada layanan yang diberikan.

\subsection{Pengaruh layanan Terhadap kepuasan konsumen}

Pada aspek layanan, penelitian mengenai layanan ekspedisi Garuda Express Delivery (GED) pada PT IDS Medical Systems Indonesia menghasilkan temuan adanya pengaruh positif dan signifikan terhadap kepuasan konsumen. Temuan tersebut menggambarkan bahwa kualitas layanan berupa Kecepatan layanan, Kehandalan layanan, Daya tanggap, Respon pada konsumen, Jaminan layanan, empati petugas dan kinerja layanan secara positif akan meningkatkan kepuasan konsumen.

Beberapa penelitian sebelumnya pada jasa pengiriman sejalan dengan penelitian ini, seperti penelitian pengaruh kualitas layanan terhadap kepuasan konsumen JNE Surabaya oleh Anshar (2019), konsumen JNE Pekanbaru (Novia \& Sutrisna, 2017), penelitian konsumen J\&T di Probolinggo (Apriati et al., 2018). Demikian pula penelitian pada 30 sampel konsumen Jasa ekspedisi Krian (Setiawan \& Frianto, 2021). Demikian pula penelitian pada sampel 100 konsumen J\&T di Samarinda (Bimantara, 2020).

Konsekuensi positif yang bisa ditindaklanjuti dari hasil penelitian ini, dimana pihak ekspedisi Garuda Express Delivery (GED) dapat memberikan atensi kebijakan dalam meningkatkan kualitas layanan berupa Kecepatan layanan, Kehandalan layanan, Daya tanggap, Respon pada konsumen, Jaminan layanan, empati petugas dan kinerja layanan. Hal tersebut terus dilakukan karena akan secara positif meningkatkan kepuasan konsumen, dalam hal ini PT IDS Medical Systems Indonesia.

\section{Kesimpulan}

Tidak terdapat pengaruh signifikan harga terhadap kepuasan konsumen. Pada sisi lain kepuasan konsumen dipengaruhi secara positif oleh kualitas layanan.

Penelitian ini diharapkan dapat bermanfaat dan dijadikan bahan pertimbangan kepada pihak-pihak yang terkait. GED bisa lebih memperhatikan lagi dalam hal kecepatan dan ketepatan pengiriman barang, khususnya dalam menjaga agar barang bisa sampai ke customer dengan kondisi baik. Selain itu, sebaiknya customer service GED dapat 
meningkatkan ketelitian dalam memberikan informasi data dan cepat dalam menanggapi keluhan.

Keterbatasan dalam penelitian ini belum melibatkan sampel pada skala industri yang lebih besar, sehingga diperlukan pengembangan pada penelitian lebih lanjut. Penelitian selanjutnya dapat dijadikan salah satu bahan referensi penelitian berikutnya dan diharapkan dapat mengembangkan lebih lanjut variabel yang sudah diteliti.

\section{Daftar Pustaka}

Anshar, A. (2019). Pengaruh Lokasi, Harga dan Kualitas Pelayanan Terhadap Kepuasan Pelanggan PT. Jalur Nugraha Ekakurir (JNE) Gunung Anyar Surabaya. Jurnal Ilmu Dan Riset Manajemen, 8(4), 1-16.

Apriati, T., Salim, M. A., \& Priyono, A. A. (2018). Jurnal Riset Manajemen Prodi Manajemen Fakultas Ekonomi Unisma. E-Jurnal Riset Manajemen, 7(2), 46-58.

Bimantara, B. (2020). Pengaruh Kualitas Pelayanan Dan Persepsi Risiko Terhadap Kepuasan Pelanggan Dalam Menggunakan Jasa Ekspedisi J \& T Express Samarinda. EJournal Administrasi Bisnis, 8(3), 258-264.

Irawan. (2009). 10 Prinsip Kepuasan Pelanggan. Jakarta. Elek Media Komputindo.

Kotler, P. \& Amstrong, G. (2012). Prinsip-prinsip Pemasaran. Jilid 1 dan 2. Edisi 12. Jakarta. Erlangga.

Kotler, P. \& Keller, K. N. (2009). Manajemen Pemasaran. Jilid I. Edisi ke 13. Jakarta: Erlangga.

Kotler, P. \& Keller, K. N. (2012). Marketing Management, 14th, Person Education.

Mulyanto, H. \& Wulandari, A. (2010). Penelitian: Metode \& Analisis. Semarang: CV.Agung.

Novia, H. E., \& Sutrisna, E. (2017). Pengaruh kualitas pelayanan dan Harga terhadap kepuasan pelanggan pada Ekspedisi di Pekanbaru. Jom Fisip, 4(2), 1-15.

Setiawan, B. P. \& Frianto, A. (2021). Pengaruh Harga dan Kualitas Pelayanan Terhadap Kepuasan Pelanggan (Studi Kasus Perusahaan Jasa Ekspedisi Krian). Journal of Business and Innovation Management. 3(1), 352-366.

Setyo, P. E. (2020). Pengaruh Citra Merk, Harga dan Kualitas Pelayanan terhadap Kepuasan Pelanggan. Jurnal Ekonomi Bisnis Manajemen Prima. 1 (2), 111 - 118

Siregar, M. K. S. (2017). Pengaruh Kualitas Produk Dan Harga Terhadap Kepuasan Konsumen Best Autoworks. PERFORMA Jurnal Manajemen dan Start-Up Bisnis. $1(6), 755-764$

Sugiyono. (2002). Statistika untuk Penelitian. Bandung. Alfabeta.

Taufik; Ayuningtyas, E. A. (2020). Dampak Pandemi COVID 19 terhadap Bisnis dan Eksistensi Platform online (The Impact of Covid-19 Pandemic on Business and Online Platform Existance). Jurnal Pengembangan Wiraswasta, 22(5), 21-32.

Tjiptono, F. (2008). Strategi Pemasaran. Edisi Ketiga. CV. Andi Offset, Yogyakarta. 